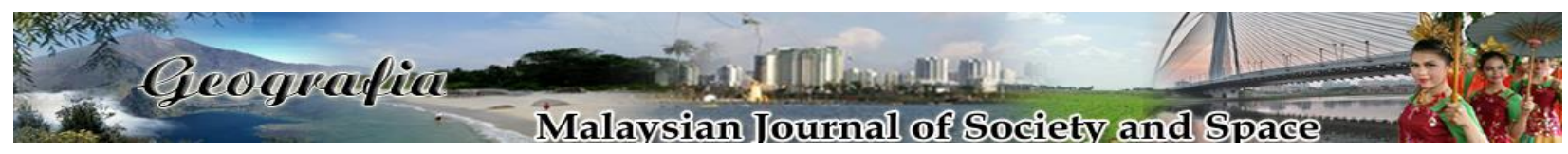

\title{
Usman Awang dan Sedili: Hubungan daripada pelancongan kesusasteraan dunia
}

\author{
Mawar Safei ${ }^{1}$, Noordeyana Tambi ${ }^{2}$, Ermy Azziaty Rozali ${ }^{3}$ \\ ${ }^{1}$ Pusat Kajian Bahasa, Kesusasteraan \& Kebudayaan Melayu, Fakulti Sains Sosial \& Kemanusiaan, \\ Universiti Kebangsaan Malaysia \\ ${ }^{2}$ Pusat Pusat Kajian Pembangunan, Sosial \& Persekitaran, Fakulti Sains Sosial \& Kemanusiaan, \\ Universiti Kebangsaan Malaysia \\ ${ }^{3}$ Pusat Kajian Bahasa Arab \& Tamadun Islam, Fakulti Pengajian Islam, Universiti Kebangsaan Malaysia \\ Correspondence: Noordeyana Tambi (email: deyana@ukm.edu.my)
}

Received: 09 March 2021; Accepted: 11 May 2021; Published: 29 May 2021

\begin{abstract}
Abstrak
Pelancongan di Malaysia rata-rata tertumpu kepada asas budaya dengan latar penduduknya yang berbilang kaum. Satu bahagian kebudayaan yang agak kurang diperhatikan adalah peranan kesusasteraan sebagai bentuk atau ragam pelancongan di Malaysia. Sejarah panjang pelancongan kesusasteraan di banyak belahan dunia seperti di United Kingdom (Shakespeare, Charles Dickens, Arthur Conan Doyle), Jepun (Basho, Ryūnosuke Akutagawa, Haruki Murakami) atau Russia (Leo Tolstoy, Anton Chekhov, Alexander Pushkin or Fyodor Dostoevsky), turut menjadi dalil keupayaan Malaysia untuk membangunkan sub genre pelancongan budaya ini. Kajian ini melihat bagaimana Malaysia yang turut mempunyai warisan kesusasteraan yang panjang, dapat mengambil pengalaman yang sama dengan mengenal pasti (i) bentuk dan ciri-ciri pelancongan kesusasteraan; dan (ii) mengenal pasti tokoh sasterawan yang dapat dinamakan sebagai titik tumpu pelancongan kesusasteraan. Kerangka kesusasteraan pelancongan digunakan untuk melihat hubungan empat mauduk, seperti (i) analisis wacana pelancongan dalam karya sastera, (ii) kajian kegiatan sastera terkait dengan pelancongan, (iii) kajian latar tempat kesasteraaan, (iv) alih wahana sastera sebagai promosi pelancongan. Dapatan kajian mengemukakan penyair Usman Awang sebagai tokoh sastera pelancongan Malaysia dengan mempertimbangkan latar kepengarangan dan latar kelahirannya di Kuala Sedili, Kota Tinggi, Johor. Usulan kegiatan sastera seperti baca puisi, persembahan teater atau diskusi karya yang diadakan dengan pengisian kembara ke Sedili meliputi tapak rumah kelahiran dan Sekolah Kebangsaan Dato' Usman Awang. Kegiatan ini boleh dilakukan dalam bentuk kerjasama pihak Yayasan Usman Awang dan Yayasan Warisan Johor. Karya Usman Awang dalam genre puisi, cerpen, drama dan muzik turut dilihat dalam lensa antara disiplin dan alih wahana seperti puisi "Kekasih", "Tanahairku” dan "Ke Makam Bonda."
\end{abstract}

Kata kunci: Kesusasteraan pelancongan, Kuala Sedili, pelancongan budaya, puisi Melayu, ragam pelancongan, Usman Awang 


\title{
Usman Awang and Sedili: Global connections to literary tourism
}

\begin{abstract}
Tourism in Malaysia generally is focused on cultural foundations with a multi-racial background. A part of the culture that is somewhat less observed is the role of literature as a form or mode of tourism in Malaysia. The long history of literary tourism in many parts of the world such as the United Kingdom (Shakespeare, Charles Dickens, Arthur Conan Doyle), Japan (Basho, Ryūnosuke Akutagawa, Haruki Murakami) or Russia (Leo Tolstoy, Anton Chekhov, Alexander Pushkin or Fyodor Dostoevsky), has been a proof of Malaysia's ability to develop this sub-genre of cultural tourism. This study looks at how Malaysia, which also has a long literary heritage, can take a similar experience by identifying (i) the forms and characteristics of literary tourism; and (ii) identify literary figures who can be named as the focal points of literary tourism. Interdisciplinary frameworks are used to look at the relationship of the four topics, such as (i) analysis of tourism discourse in literary works, (ii) study of literary activities related to tourism, (iii) study of literary setting, (iv) cross media as tourism promotion. The findings of the study presented the poet Usman Awang as a Malaysian tourism literary figure by considering his authorship and birth background in Kuala Sedili, Kota Tinggi, Johor. Proposals for literary activities such as Usman Awang's Remembrance Day held with a trip to Sedili, to visit the birthplace and the primary school of Dato Usman with the collaboration of Usman Awang Foundation and Johor Heritage Foundation. Usman Awang's work in the genres of poetry, short stories, plays and music is also seen from the perspective of interdisciplinary and cross media such as the poem "Kekasih", "Tanahairku" dan "Ke Makam Bonda."
\end{abstract}

Keywords: Cultural tourism, Kuala Sedili, literary tourism, Malay poetry, tourism patterns, Usman Awang

\section{Pengenalan}

Kesusasteraan sebenarnya menikmati banyak kurnia dari wilayah pelancongan. Latar alam, tokohtokoh yang menjadi penambat atau bangunan yang mempunyai cerita yang tersendiri, sering merupakan ilham dalam kalangan sasterawan. Sebaliknya juga novel, puisi atau cerita pendek yang digubah para sasterawan yang kreatif dan imaginatif, menawarkan ruang yang luas dalam penggemblengan industri pelancongan. Menerusi kesusasteraan, bagaimana ia dapat menjadi bahan iklan dan dagangan untuk melariskan tapak pelancongan. Diperlihatkan juga bagaimana karya sastera yang merakam latar atau tokoh benar, menjadi "besi semberani" (Preston, 1992) yang menarik kuat pelawat untuk datang menziarahi "teks realiti" yang selama ini hanya dibaca dari halaman buku-buku.

Sejarah dan perkembangan kesusasteraan pelancongan dunia, sebagai salah satu capahan sub pelancongan, memperagakan banyak dalil hubungan timbal balik atau kesalingan ini. Contoh dari tanah Inggeris United Kingdom misalnya bagaimana sebilangan besar pelancong melawat rumah kelahiran William Shakespeare di Waterside, Stratford-upon-Avon. Malah meja dan penjuru kafe yang digunakan J.K. Rowling di café The Elephant House, Edinburgh, untuk 
mengarang novel Harry Potter, pasti mahu disinggahi para peminat. Mereka mahu merasakan bersama-sama watak fantasi di Hogwarts School of Witchcraft and Wizardry.

Sementara di Fukagawa, Jepun, betapa bahagianya bagi seorang peminat Basho, penyair haiku masyhur itu, untuk dapat ke Basho Memorial Hall bagi melihat sendiri haiku yang digubah antaranya yang dilakar di atas batu di taman Basho-An Historic View sambil menikmati pemandangan Sungai Sumida di sepanjangnya. Begitu juga nama-nama bandar yang dikemukakan Haruki Murakami, seperti Kobe dalam novel pertamanya, Hear the Wind Sing (1979). Kobe merupakan wilayah asal Murakami dan watak utama dilahirkan. Beberapa nama tempat yang disebut seperti taman Uchide, perpustakaan tua di Ashiya, dan kafe J mahu dilawat semula setelah bertemu di atas baris-baris gubahan pengarang (Nakamura, 2015). Novel yang difilemkan oleh Kazuki Omori pada 1981 ini menggiatkan lagi kesan visual daripada teks novel untuk penggemar novel ini melawati tempat dan latar berkenaan.

Kedatangan pelancong ke Russia pasti turut akan menziarahi muzium sastera dan adanya pakej lawatan ke rumah kelahiran antara sasterawan besar mereka seperti Leo Tolstoy, Anton Chekhov, Alexander Pushkin or Fyodor Dostoevsky. Karya yang dihasilkan seperti War and Peace (Leo Tolstoy, 1869), The Brothers Karamazov (Fyodor Dostoevsky, 1880), Dr Zhivago (Boris Paternak, 1957) yang kemudiannya diadaptasi ke filem, turut memberikan tanggapan dalam hubungan kesusasteraan dengan sektor pelancongan menerusi kreativiti alih wahana.

Pengalaman Indonesia melalui kepengarangan Andrea Hirata dalam Laskar Pelangi (2005) misalnya meningkatkan kadar pertambahan pelancong ke Belitong. Tarikan itu dikaitkan dengan lokasi sekolah Muhammadiyah dan latar Linggang dan Tanjung Tinggi dalam novel yang kemudiannya diadaptasi ke filem (2008). Laskar Pelangi meraih filem terbaik dalam Festival Filem Indonesia (2009). dan Pemerintah tempatan juga menawarkan pakej pelancongan ke pulau itu dalam rangka Tahun Melawat Belitung 2010. Malah tapak sekolah yang sudah tidak ada itu, dibangunkan semula mengikut reka bentuk asalnya. Dalam kasus Indonesia khasnya di Sumatera Barat, beberapa sosok sasterawan lainnya turut menikmati kesan ekonomi menerusi "sastra wisata"nya seperti rumah kelahiran sasterawan ulama Hamka di Maninjau, kota Padang padanan dengan novel Sitti Nurbaya oleh Marah Rusli atau rumah penyair Taufiq Ismail di Padang Panjang.

Merujuk kepada pelancongan keagamaan di Turki pula, kota Konya menjadi tanda aras yang signifikan. Kota ini begitu sinonim dengan tokoh penyair yang terkenal di dunia ialah Mevlana Jalaluddin al-Rumi. Rumi adalah salah seorang penyair yang paling banyak dibaca karyanya di dunia. Selama hidupnya, dan sejak kematiannya pada tahun 1273, ramai pengunjung atau pelancong telah datang ke Konya. Ziarah mereka merupakan perjalanan kesejahteraan jiwa (Karimi, 2019). Statistik kedatangan pelancong luar negara ke Turki pada 2013 misalnya menunjukkan penambahan 10 peratus dari tahun sebelumnya, iaitu sebanyak 34.9 juta orang. Dapatan angka ini memberi kedudukan Turki di tempat keenam untuk tiga tahun yang menawarkan pendapatan sebanyak $\$ 25.3$ bilion (WTO, 2014). Malah pada tahun yang sama, sektor pelancongannya menjana kurang lebih 11 peratus daripada keluaran dalam negeri kasar (GDP) dengan penglibatan 2.1 juta tenaga kerja (atau 8.4 peratus daripada penduduk) (Kartal, 2015). Muzium Rumi di Konya menjadi daya tarikan pelancong dan menjadi lokasi kedua tertinggi yang tertinggi selepas Istana Topkapi (Murat Kocyigit, 2016). Menurut rekod muzium Rumi menerima hampir 3.5 juta pelancong pada tahun 2019 yang datang daripada pelbagai negara seperti Iran, Taiwan, Amerika dan Korea Selatan.

Sepertimana pengalaman tanah Inggeris, Jepun, Russia, Indonesia dan Turki dengan tokoh kesusasteraan masing-masing, Malaysia turut mempunyai latar kesusasteraan yang panjang. Lingkungan sastera tradisional, teks kanon seperti Sejarah Melayu atau Hikayat Hang Tuah atau 
dengan latar dan watak yang dibentangkan, rata-rata dapat menjadi tarikan. Proses alih wahana daripada teks ke filem seperti yang dialami The Hobbits misalnya, turut pernah dan sedang dilakukan di Malaysia. Misalnya bagaimana epik Merong Mahawangsa dan Puteri Gunung Ledang dan Hang Tuah pernah dipindahkan ke layar filem (Nor Hashimah Jalaludin, 2019). Meluaskan peluang pembacaan teks sastera ke ruang genre atau media lain, dapat melebarkan jangkauan perhatian dan minat khalayak. Ia secara tidak langsung menjadi alat iklan untuk mereka melawat latar yang diperagakan dalam karya berkenaan.

Perkembangan kesusasteraan Melayu seterusnya di tangan Sasterawan Negara (SN), ternyata karya mereka turut diiktiraf di peringkat antarabangsa, dapat menjadi pancingan kegiatan kesusasteraan pelancongan ini. Misalnya hampir kebanyakan SN merupakan penerima Anugerah SEA Write dari kerajaan Thai. Karya besar mereka yang melalui jalan terjemahan ke pelbagai bahasa dunia, merupakan rumus penyebaran maklumat kesusasteraan Melayu lebih luas lagi. Contohnya novel SN Anwar Ridhwan Hari-hari Terakhir Seorang Seniman (1979) yang diterjemahkan ke bahasa Inggeris The Last Days of an Artist (1982) oleh Harry Aveling dan ke bahasa Perancis Les Derniers Jour D’un Artist (2009) oleh Monique Zaini-Lajoubert. Maka kesusasteraan Melayu dilihat dapat menjadi taruhan dalam menggiatkan lagi membawa pelancong datang melawat ke tempat-tempat yang ditemukan dalam karya para sasterawan berkenaan. Maka penulisan ini menumpukan perhatian terhadap hubungan kesusasteraan dan pelancongan yang dapat dibangunkan lebih giat di Malaysia dengan berpandukan kepada pengalaman negara luar lain, antaranya mungkin sahaja dalam wilayah pelancongan kesusasteraan yang mengambil kerangka Islami (Jabil Mapjabil, 2015).

\section{Ulasan literatur}

Banyak kajian tentang hubungan timbal balik antara kesusasteraan dengan pelancongan. Antara lensa yang dimanfaatkan adalah dari pulangan ekonomi, manfaat kesasteraannya dan juga strategi yang digembleng sastera menerusi kerja alih wahana bagi meningkatkan perhatian terhadap nilai kesasteraan yang akhirnya menjadi daya tarikan pelancongan khasnya dalam kalangan mereka yang membaca karya yang dihasilkan.

Bidaki dan Hosseini (2014) melihat kesusasteraan sebagai satu pendekatan moden dalam pertumbuhan pelancongan Tajikistan. Ternyata kesusasteraan pelancongan ini menjadi satu kurnia apabila ia dapat menjana pekerjaan dalam pelbagai sektor melibatkan banyak capahan jenis perkhidmatan dan pada masa yang sama menambah baik prasarana tempatan. Pengkaji mengambil Rudaki, dalam tulisan, "Literary Tourism as a Modern Approach for Development of Tourism in Tajikistan", penyair kelahiran Panjrud yang dibutakan oleh pihak penentang. Dengan mengambil pertimbangan tiga bentuk pancingan, iaitu latar sebenar, latar ciptaan dan latar yang dibangunkan untuk tujuan pelancongan, mereka menyelidik ketokohan Abu Abdullah Rudaki, Bapa Kesusasteraan Parsi. Menjejaki kepengarangan Rudaki menyeberang beraneka wilayah geografi dalam kerangka touristic path, merupakan satu agenda pelancongan yang menarik dalam menerapkan karya sastera sebagai modal besarnya. Dalam kasus Rudaki, tapak kelahirannya di perkampungan Rudak, Panjrud, menjadi titik mula para pelancong mengenali bukan sahaja puisinya malah kemudian menebar kepada sejarah, budaya dan Tajikistan secara umum. Jejak kesasteraan ini (literary path) ini sangat menuntut tiga paksi mustahak ini, iaitu penyelidikan saintifik, fahaman asas, dan mengulang kaji wajah sejarah yang memberi kesan ke atas pelancongan kesusasteraan itu sendiri. 
Gabriela-Cosmina Tudor (2015) melihat proses alih wahana dalam "Film Tourism - A Successful Journey for New Zealand: The Way Towards Being the World's Top Film Tourism Destination." Pengalaman besar yang pernah dijalani siri filem The Hobbit Lord of the Rings di New Zealand. Mereka memanfaatkan karya alih wahana dari novel ke filem, meletakkan kedudukan pelancongan filem (film tourism) sebagai satu fenomena di negara berkenaan. Kajian Tudor membuktikan strategi pemasaran oleh pihak kerajaan dan kepakaran yang ada, menjayakan usaha mereka. Siri ini mengandungi tiga filem, iaitu The Hobbit: An Unexpected Journey (2012), The Hobbit: The Desolation of Smaug (2013), dan The Hobbit: The Battle of the Five Armies (2014). The Hobbit diilhamkan pengarah Peter Jackson dari novel berjudul yang sama karya J.R.R. Tolkien pada 1937. Kajian Tudor (2015) memperakukan ia memberikan perubahan landskap New Zealand sebagai negara pengeluar bahan tenusu kepada negara utama pelancongan filem di dunia. Ia antara lain memperlihatkan kecenderungan pelancong ke New Zealand adalah kerana tarikan dari filem trilogi Lord of the Rings tersebut. Wawancara yang dilakukan The Forbes pada 2012 dengan Pengurus Besar Western Long Haul Markets untuk pelancongan New Zealand, Gregg Anderson, mengemukakan pertambahan $50 \%$ kedatangan pelancong sejak filem pertama trilogi Lord of the Rings pada 2001.

Firsova, Anastasia \& Svetlana Myshlyavtseva (2019) menulis tentang dampak karya sastera seperti yang berlaku pada novel Dr Zhivago karya Boris Pasternak, dalam prosiding mereka yang berjudul "The Literary Heritage of Boris Pasternak as a Resource for the Project Management in Tourism." Novel karangan sasterawan Russia kedua yang menerima Hadiah Nobel Kesusasteraan (1958) selepas Ivan Bunin (1933), ini didakwa dapat merubah sosok dan sosioekonomi perkampungan Vsevolodo-Vilva, Perm Krai, kawasan kediaman Pasternak pada 1961. Yuryatin dan Varykino merupakan produk pelancongan yang dibangunkan menerusi $\mathrm{Dr}$ Zhivago. Memanfaatkan kaedah yang pragmatik dalam melihat kesalingan hubungan kesusasteraan dengan membangunkan sektor pelancongan di Russia. Bagaimana usaha sama pemerintah tempatan mengenal pasti ruang, faktor tarikan, bahan kenangan dan acara sasterabudaya yang memastikan kelestarian lokasi ini sebagai destinasi pelancongan dunia. Misalnya bagaimana dibangunkan "Rumah Pasternak" (Perm the Great) menjadi pusat sejarah dan kebudayaan dengan dukungan wilayah pemerintah Perm dengan upaya yang dijalankan masyarakat setempat, sasterawan dan Yayasan Kebudayaan Yuryatin pada 2008. Penghargaan mereka terhadap menghidupkan terus semangat Dr Zhivago. Pelancong yang datang akan dapat melihat sejarah, budaya, program pendidikan, lawatan muzium dan akhirnya dalam rangka lawatan itu penziarah akan dapat melihat secara keseluruhan keindahan landskap bukan hanya sisi kesusasteraan tetapi latar alam dengan aliran sungai Vilva, Usva dan Kosva pergunungan Ural. Dianjurkan juga acara kesusasteraan bersama penulis, sejarawan dan budayawan.

Secara umumnya, pelancongan di Malaysia tertumpu kepada asas budaya dengan latar penduduknya yang berbilang kaum. Satu bahagian kebudayaan yang agak tidak diperhatikan adalah peranan kesusasteraan sebagai bentuk/ragam pelancongan di Malaysia. Merujuk kepada definisi menunjukkan bahawa pelancongan kesusasteraan termasuk di bawah warisan kebudayaan dari sudut warisan cara hidup rakyat Malaysia (sejarah) bukan warisan semula jadi. Ia meletakkan pelancongan sastera sebagai sub pelancongan budaya. Berbanding dengan beberapa negara lain, pelancongan kesusasteraan (literary tourism) merupakan antara tarikan yang tidak kurang pentingnya. Oleh itu, kajian ini melihat bagaimana Malaysia yang turut mempunyai warisan kesusasteraan yang panjang, dapat mengambil pengalaman yang sama. Lebih-lebih lagi sebagai sebuah negara Islam, para sasterawan Melayu banyak menyumbang dari zaman awal, diyakini turut mempunyai kekuatan ke arah pembikinan "daerah pelancongan” mereka. Maka, kajian ini 
cuba merungkai bagaimanakah kedudukan kesusasteraan di Malaysia dapat dimanfaatkan sebagai salah satu cabang pelancongan. Bagaimana dengan kedudukan itu kesusasteraan dapat menyumbang terhadap pendapatan negara menerusi kegiatan pelancongannya. Maka penelitian ini menjurus dua keperluannya, iaitu (i) mengenal pasti bentuk dan ciri-ciri pelancongan kesusasteraan di Malaysia; dan (ii) mengenal pasti tokoh sasterawan yang dapat dinamakan sebagai titik tumpu pelancongan kesusasteraan berdasarkan karya dan lokasi bersejarahnya sama ada tapak rumah kelahiran, kediaman yang diduduki, permakamannya atau nama-nama lokasi tertentu.

\section{Pelancongan kesusasteraan}

Fenomena pelancongan sebagai pergerakan manusia ke merata tempat yang dihajati dan disenangi, menjadi pulangan ekonomi yang luar biasa, dan pada masa yang sama membentangkan aneka bentuk pelancongan. Antara ragam pelancongan itu seperti pelancongan tani (agritourism), pelancongan eko (ecotourism), pelancongan kesihatan (medical tourism), pelancongan pendidikan (education tourism) termasuk pelancongan kesusasteraan (literary tourism). Keanekaragaman pelancongan ini memberikan isyarat betapa wilayah ekonomi ini wajar diberikan perhatian sebaiknya.

Tumpuan dalam penulisan ini, pelancongan kesusasteraan adalah sebahagian daripada pelancongan budaya dan warisan yang mewakili lokasi sebenar di sesebuah kawasan berikutan daripada latar dan tokoh yang masyhur (Hoppen, Brown, \& Fyall, 2014; Ghetau, Leontina, \& Esanu, 2011). Konsep pelancongan kesusasteraan ini bermula di United Kingdom pada sekitar penghujung abad ke-18 dalam kalangan generasi muda ketika itu. Namun lebih awal daripada itu dirakam sejarah, Petrarch semasa Empayar Rom berlangsung sudah melihat jalinan hubungan antara kesusasteraan dengan pelancongan (Akarcay, 2017). Fahaman ini terus tersebar di merata belahan dunia termasuk Eropah dan Amerika; ia kemudiannya kian dilihat secara saksama dari sudut pandang akademik juga.

Pelancongan kesusasteraan merupakan belahan industri pelancongan yang berhubung rapat dengan karya sastera, pengarang yang menghasilkannya, tempat lahir pengarang, latar peristiwa dan perwatakan dalam karya tersebut, malah pemakaman pengarang. Kesemua ini merupakan "impian" semasa perjalanan pembacaan dan datang ia didatangi secara bersemuka dan ia kemudiannya merupakan acara "memenuhi impian" awalnya. Pembaca yang selama ini hanya mengikuti perjalanan hidup pengarang dan gubahan naratifnya pada baris halaman buku, saat berhadapan dengan kenyataan merupakan detik yang mengujakan. Dapat melihat sendiri tapak rumah kelahiran, menjejaki jalan, bangunan warisan lama, perkampungan, pantai, pergunungan atau pemakaman atau lokasi yang dinyatakan pengarang dalam karyanya, merupakan satu kepuasan estetika. Pembaca dapat melalui pengalaman batiniah menyatukan diri mereka dengan karya pengarang, malah diri pengarang. Proses rentas-kod (trans-codification) di antara "kenyataan" dengan "impian" itu sebenarnya yang memasuki wilayah emosi dan memori pembaca/pelancong dan inilah yang mendasari falsafah asas kesusasteraan pelancongan.

Pengalaman batiniah pembaca itu lebih-lebih lagi terkesan apabila karya cetakan yang dipegang itu melalui pelbagai bentuk pengiklanan lainnya. Misalnya apabila novel, cerpen atau puisi itu dipindahkan ke dalam media filem atau lagu yang lebih menambah minat dan keakraban dengan kepengarangan. Ada kesan limpahan estetik dalam ruang media yang baru itu. Ia melebarkan lagi horizon apresiasi lalu meningkatkan keazaman pembaca karya untuk hadir sendiri ke lokasi yang terkait itu. Kesan rebakkan (ripple effect) seperti ini yang lebih memasyhurkan 
petempatan yang menjadi latar karya seperti yang berlaku pada novel-novel yang dikemukakan sebelum ini seperti Harry Potter, Laskar Pelangi, Sitti Nurbaya, Lord of the Rings atau Dr Zhivago.

\section{Metodologi kajian}

Penelitian ini secara umumnya menggunakan kaedah kualitatif dengan kajian kepustakaan ke atas bacaan lepas yang pernah dijalankan. Kekangan untuk merentas negeri akibat penularan wabah Covid 19, kajian ini hanya dapat memanfaatkan satu wawancara secara atas talian yang dijalankan dengan Rozninah Mohd Azib, mantan Editor Dewan Sastera yang berasal dari Kuala Sedili. Beliau juga mempunyai hubungan keluarga dengan Usman Awang dan kebetulan bermula 2019, berada di Kuala Sedili untuk menguruskan ayahnya yang uzur. Beberapa soalan yang dimajukan dalam wawancara atas talian itu antara lain menjawab tentang kedudukan Kuala Sedili dan kepenyairan Usman Awang.

Beberapa definisi kesusasteraan pelancongan dirujuk, antaranya oleh Samet Cevik (2018). Rata-rata dirumuskan bahawa terdapat empat klasifikasi pelancongan kesusasteraan, iaitu:

i. latar tempat sebenar yang berhubungan dengan pengarang sama ada lokasi kelahiran, kediaman atau kuburannya;

ii. latar tempat yang diperagakan secara tekal dalam karya sehingga pembaca mahu mengunjunginya;

iii. latar tempat yang dikaitkan figura dalam karya kesusasteraan; dan

iv. karya sastera mendapat populariti apabila lokasi dan tempat yang berkaitan menjadi tumpuan pelancong seterusnya menjadi destinasi pelancongan.

Bidaki dan Hosseini (2014) pula menyebut tiga latar yang merupakan tarikan pelancongan kesusasteraan, iaitu menerusi pemeragaan:

i. latar sebenar

ii. latar ciptaan dalam karya sastera

iii. latar yang dibangunkan untuk tujuan pengiklanan pelancongan

Kerangka ini digunakan untuk melihat hubungan sasterawan yang ditumpukan dengan empat pemerihalan itu, (i) analisis wacana pelancongan dalam karya sastera, (ii) kajian kegiatan sastera terkait dengan pelancongan, (iii) kajian latar tempat kesasteraaan, (iv) alih wahana sastera sebagai promosi pelancongan.

Kerangka ini ditinjau dalam wilayah kesusasteraan Malaysia. Rata-rata terdapat beberapa penulis di Malaysia yang mempunyai idiosinkrasi yang jelas dengan latar tempat khasnya tempat kelahiran dan kediaman mereka. Misalnya Shahnon Ahmad kerap menamakan Kampung Banggul Derdap dalam novelnya seperti Rentong, Ranjau Sepanjang Jalan dan Srengenge. Sementara Usman Awang mengambil latar kelahirannya Kuala Sedili dalam puisi; dan bagaimana S. Othman Kelantan sering menamakan Kota Bahru dalam novelnya. Pada kesempatan kajian ini, kepenyairan Usman Awang dilihat sebagai satu tarikan untuk penikmat puisi-puisinya ke Kuala Sedili, perkampungan kelahirannya. 


\section{Dapatan kajian dan perbincangan}

\section{Pelancongan kesusasteraan Malaysia}

Mengambil pengalaman beberapa negara luar yang terlibat dalam kesusasteraan pelancongan, tulisan ini melihat bagaimana kesusasteraan Malaysia khasnya kesusasteraan Melayu dapat memanfaatkannya. Misalnya menggunakan kerangka Samet Cevik (2018) dan Bidaki (2014) kajian ini merumuskan berikut sebagai acuan menganalisis kedudukan Usman Awang dalam wilayah kesusasteraan pelancongan;

i. latar tempat lahir, tempat tinggal atau tempat kematian;

ii. latar yang tekal diperagakan dalam karya;

iii. latar sepanjang jejak-jejak kesasteraan

Penelitian ini menumpukan kepada sasterawan Usman Awang dengan latar Kuala Sedili sebagai kajian kes kesusasteraan pelancongan di Malaysia. Usman Awang merupakan Sasterawan Negara Malaysia yang ketiga (1993) selepas Keris Mas dan Shahnon Ahmad. Masyhur dengan nama pena Tongkat Warrat khasnya dalam genre puisi, di samping banyak menulis dalam genre cerpen, drama dan novel tunggalnya, Tulang-tulang Berserakan (1966, Pustaka Melayu Baru). Beberapa kumpulan puisinya seperti Gelombang (1961), Duri dan Api (1967) dan Salam Benua (1982). Sementara kumpulan cerpennya adalah Degup Jantung (1963), Ini Saya Punya Kerja (Othman Puteh, 1999) dan Kami yang Terlibat - Cerpen Pilihan Abad ke-20 (2007). Beberapa drama masyhur seperti Serunai Malam (1966), Matinya Seorang Pahlawan (1997) dan Tamu Bukit Kenny (1976). Usman Awang meninggal dunia pada 29 November 2001 dan disemadikan di Tanah Perkuburan Islam Bukit Kiara.

Usman Awang dilahirkan pada 12 Julai 1929 di Sedili, Kota Tinggi, Johor. Nama Sedili secara khas muncul dalam puisinya, "Kuala Sedili" yang diletakkan dalam penggalan atau fragmen puisi-puisi yang ditulis pada 1958-60 di bawah judul "Debu Berterbangan" (Gelombang, 1988; terbitan pertama 1961). Diksi dan latar "Sedili" ini mengambil suasana perkampungan nelayan sebagaimana tempat lahir penyair; ia ditandakan pada baris ketiga rangkap pertama /tangisku pertama bergemal,

Sepinya tanah kelahiran untukku dari kota dalam serba gelisah berpura sesuai merasa di sinilah, O Kuala Sedili, tangisku pertama bergema Pada rumput menghijau seperti kesuburan kasih ibu ah, kenangan ketika kecil di bumi Tanjung Lembu sampai kini Sungai Sedili terbentang seperti dulu.

Dari sini kulihat payang dengan layar putih di dalamnya ikan-ikan segar bukan milik mereka lagi ayahku di tiang layar, bersama paman jurumudi Siapa bisa mengerti bahawa hidup demikian membara dalam kepahitan menyesak masih jua terdengar tertawa; itulah kebanggaan mereka menyarai usus-usus keluarga. Tapi derita bagi mereka apakah erti bila mereka di dalamnya, tak merasa lagi sebab tak dilihat mata, menjadi pusaka untuk kami 
Ungkapan pada judul puisi ini sendiri, "Kuala Sedili”, nama "Tanjung Lembu” pada rangkap kedua (petikan baris ah, kenangan ketika kecil di bumi Tanjung Lembu), rata-rata menimbulkan pertanyaan malah kekeliruan tentang fakta kelahiran sebenar Usman Awang. Nama "Tanjung Sedili" dan "Kuala Sedili" merupakan nama tempat di Kota Tinggi, Johor yang pasti menawarkan latar tempat yang berbeza. Terdapat beberapa versi penerangan tentang dua latar ini terkait dengan lokasi asal kelahiran Usman Awang; berdasarkan tulisan antaranya oleh Muhammad Haji Salleh (2017) dan kebanyakan maklumat dari atas talian (laman sesawang Wikipedia, Yayasan Usman Awang, Penyair Wordpress). Rata-rata dinyatakan tempat lahir Usman Awang adalah di Kampung Tanjung Lembu, Kuala Sedili. Begitu dilihat dua latar tempat yang disebut Usman Awang dalam baris puisi "Kuala Sedili", iaitu "Kuala Sedili" dan "Tanjung Lembu."

Menurut kebanyakan sumber atas talian (laman sesawang umum) yang menyatakan sejarah Tanjung Lembu adalah nama lama bagi Tanjung Sedili. Satu laman rasmi kerajaan, Pejabat Kesihatan Daerah Kota Tinggi (https://www.pkdkt.com/index.php?option=com_ content\&view=article\&id=62\&Itemid=61), juga menamakan Tanjung Sedili sebagai,

... sebuah kawasan di daerah Kota Tinggi, Johor, Malaysia. Terletak di muara Sungai Sedili di pinggir Laut China Selatan, kira-kira 40 kilometer dari Bandar Kota Tinggi, kawasan ini dibahagikan kepada tiga kawasan utama, iaitu Tanjung Sedili, Sedili Besar dan Sedili Kecil.

Terdapat juga peta yang jelas menggunakan nama yang masih mengelirukan. Kedudukan nama "Kampung Tanjung Lembu" yang berada di seberang "Tanjung Sedili Besar" seperti Rajah 1 .

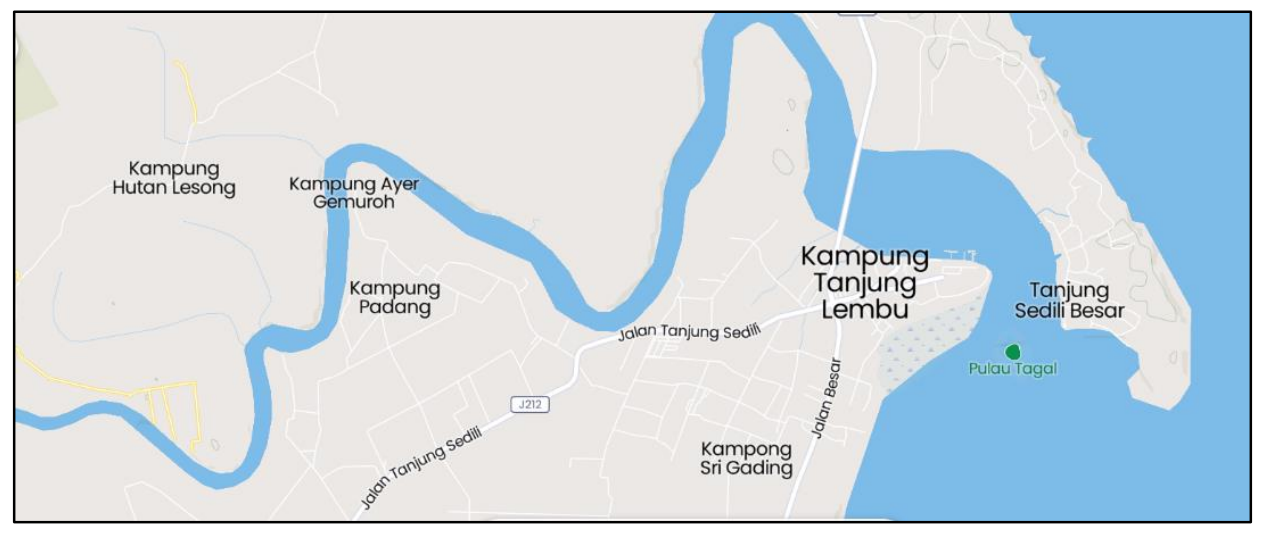

(Sumber: mapcarta.com)

Rajah 1. Peta Sedili.

Sementara itu terdapat maklumat lain yang mengemukakan kedudukan Kuala Sedili terdiri daripada tiga buah kampung, iaitu (i) Kampung Tanjung, (ii) Kampung Tengah, dan (iii) Kampung Bukit. Ahli keluarga Usman Awang, masih menegaskan bahawa Sasterawan Negara itu dilahirkan di Kuala Sedili (Besar), iaitu di Kampung Tengah (Rozninah Abd. Azib, 2021).

Walau bagaimanapun tapak rumah kelahiran Usman Awang di Kampung Tengah, Kuala Sedili “sudah hilang” akibat perkelanaannya, ke Melaka, Singapura, malah ke segala penjuru dunia dan berakhir di Kuala Lumpur (2001). Semasa hayatnya pulang Usman Awang ke Sedili bermakna adalah ke Tanjung Sedili, iaitu ke rumah yang dibangunkan buat ibu tirinya (Rozninah Abd. Azib, 
2021). Pulang ke Tanjung Sedili, Usman Awang masih menziarahi saudara mara yang masih ada di Kuala Sedili (Sedili Besar). Maka kedudukan "Sedili" ini seperti padang keemasan "The Daffodils" dan Dove Cottage di Grasmere yang membawa cepat ingatan pencinta puisi penyair romantis abad ke-19 Inggeris, William Wordsworth. Tanpa latar tempat kelahiran yang asal, Usman Awang dan "Sedili" masih dapat dipertahankan kedudukannya dalam wilayah kesusasteraan pelancongan. Begitu para peminatnya membaca kisah perih nelayan dalam puisi "Kuala Sedili" dan "Nelayan." Diperlihatkan lagi jadual hidup nelayan di Sedili dalam "Kuala Sedili":

Dari pemergian subuh-subuh sampai pulang tanpa keluhan pada matahari dan laut menggeram selain wajah-wajah menggelepar dari kepahitan mendalam Apakah yang mendorong ketabahan seperti batu karang kalau hati yang pengasih itu sentiasa menyatakan segempal nasi bagi kami anak-anak penyambung kemiskinan?

Tidak ada kesedihan, barangkali hanya kematian, sebab dalam kesakitan mereka bisa mengemudi payang; semua telah berpadu seperti air dan garam di lautan Hanya wajah-wajah tua ketika musim tengkujuh serupa daun-daun berguguran seluruh jadi rapuh pintu maut sedang terbuka dari perut laut gemuruh O tanah kelahiran, betapa kau mimpikan elektrik sinar menyinar gemilang yang menghidupkan pekat malam sebab kau bumi nelayan yang berhak menerima kesuraman.

Membaca puisi "Kuala Sedili" dan kebanyakan puisi Usman Awang, apa yang ditemukan adalah nada kemanusiaan (Lim Swee Tin, 1999). Di satu pihak lain, Rahman Shaari mengangkat tokoh ini sebagai penyair humanis dengan memberikan contoh pada puisi Usman Awang yang berjudul "Kemanusiaan" (Salam Benua, 1982: x). Begitu juga catatan "Pendahuluan" Syed Hussin Ali dalam Anak Jiran Tionghua: 50 Sajak Perpaduan dan Keamanan (Haslina, 2017), banyak nilai luhur yang diperoleh daripada puisi-puisi Usman Awang dan tiga nilai yang terpenting adalah kemanusiaan, keadilan dan perpaduan (hlm. ix).

Maka makna ziarah para penikmat karya penerima Hadiah SEA Writes 1982 ini juga sebenarnya cuba menjejaki bahasa nuraninya. Membaca kebanyakan puisinya yang lain seperti "Kaum Buruh", "Orang tak Berbaju” dan "Penjual Air Batu”, sangat mengheret pembaca ke ruang apa yang dikatakan Syed Hussin Ali tiga nilai terpenting itu. 


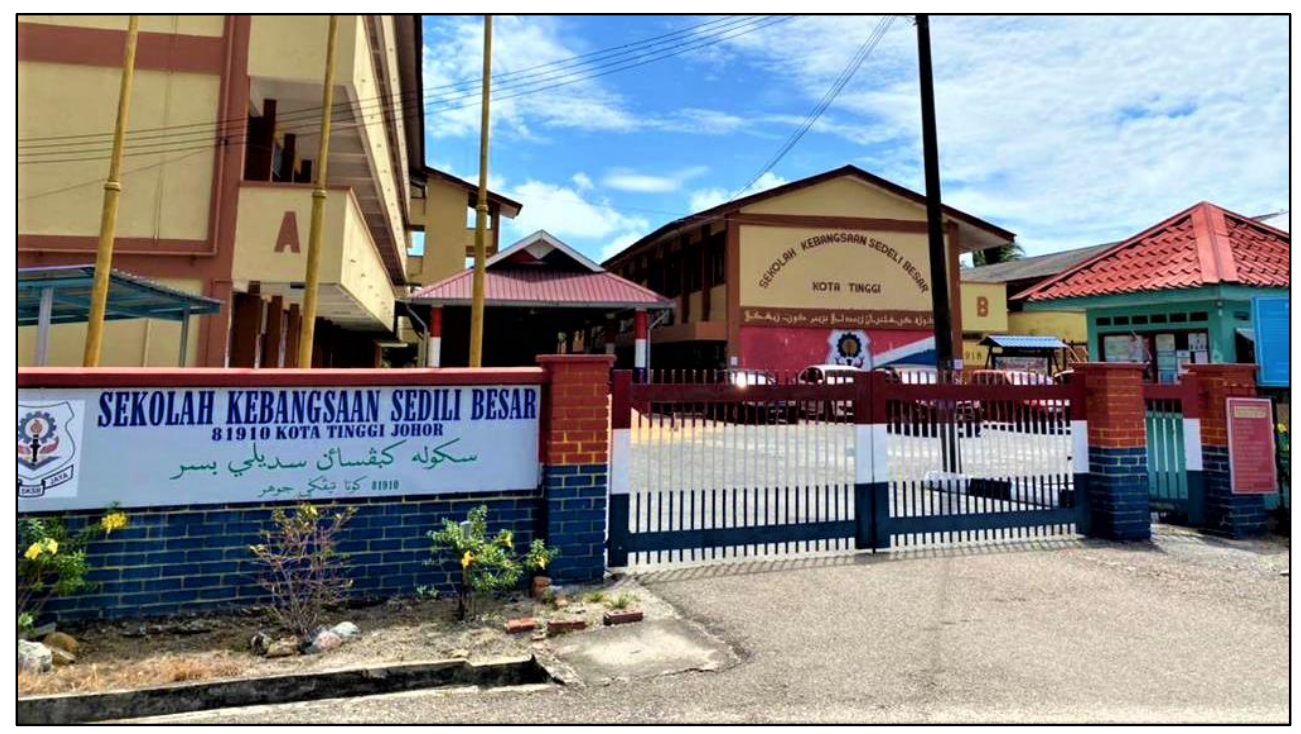

(Sumber: Rozninah Abd. Azib, 2021)

Rajah 2. Sekolah pertama Usman Awang.

Kehidupan awalnya di perkampungan nelayan, sangat memberi dampak besar terhadap kepenyairannya. Berpendidikan hanya sehingga darjah enam sekolah Melayu iaitu di Kuala Sedili (1936) (Foto 2) dan Bandar Maharani (1940). Namun seperti kenyataan beberapa pengkaji, Usman Awang adalah penyair kemanusiaan (Rahman, 1982; Swee Tin, 1999; Anwar, 2015). Perhatikan bagaimana Usman Awang menyatakan dukungannya terhadap golongan murba yang terdiri daripada nelayan dan buruh, misalnya dalam puisi "Nelayan" (Usman Awang, 1979: 12) berikut:

Dalam pagi-pagi nian,

Terdengar irama kayuh nelayan,

Berkecimpung di air dalam membiru,

Penuh lagu sedih sayu.

Walau tegas jasad melandai segara,

Dalam biduk kecil selebar upih,

Namun derita tak kunjung reda,

Dalam desakan hidup merintih.

Puisi ini diletakkan dalam penggalan pertama puisi-puisi yang ditulis pada 1949-1956 di bawah judul "Bintang-bintang Mengerlip" (Gelombang, 1988; terbitan pertama 1961). Kedudukan para nelayan ini rata-rata dapat dibandingkan dengan kajian Zaimah (2015) terhadap tahap kesejahteraan hidup nelayan di Sedili, meliputi nelayan pantai ataupun nelayan laut dalam,

Purata pendapatan responden daripada pekerjaan sebagai nelayan ialah RM713.00 sebulan. Purata garis kemiskinan kasar negeri Johor RM634 sebulan (Malaysia, 2006), bermakna responden berjaya melepasi kadar tersebut. Walaupun begitu, rata-rata responden mempunyai pendapatan bulanan antara RM500.00 hingga RM1,000.00 sebulan (82\%) dan ia masih dalam kumpulan 40 peratus penduduk berpendapatan rendah (Malaysia, 2010). Jika dilihat purata pendapatan bulanan isi rumah pula, ia mencatatkan sebanyak RM1,021.30 sebulan. 
Ternyata nasib nelayan Sedili sejak puisi "Nelayan" digubah, masih meletakkan mereka sebagai kumpulan pekerja yang harus diperhatikan dari sudut ekonomi, sosial dan kemanusiaan. Pelbagai pengalaman hidup Usman Awang sebagai buruh paksa semasa pendudukan Jepun di Singapura, anggota polis di Johor Bahru dan Melaka, sebelum menyertai dunia kewartawanan dan penulisan yang berakhir di Dewan Bahasa dan Pustaka sebagi Ketua Bahagian pada 1985.

Catatan Ismail Hussein dalam kata pengantar Gelombang yang ditulis pada 1961 tentang puisi Usman Awang:

... Pengaruhnya pula bukan terbatas di kalangan masyarakat Melayu. Usman mendapat perhatian yang luas daripada masyarakat Tionghoa (sic), lebih luas saya rasa daripada pengarang-pengarang Melayu yang lain....

Penerimaan hasil-hasil Usman oleh masyarakat Tionghoa (sic) ini memberikan kepada kedudukan yang agak istimewa, dan di samping itu memberikan pula harapan kepada kita bahawa mungkin dalam ciptaan-ciptaannya ini dapat kita temui unsur-unsur yang dapat dijadikan dasar untuk pembinaan kesusasteraan kebangsaan kita nanti.

(Usman Awang, 1988, ix)

Didapati semangat "kemanusiaan, keadilan dan perpaduan" Usman Awang ini dilanjutkan dalam bentuk pengiktirafan kepada individu atau pihak yang menyahut semboyan tersebut menerusi Anugerah Integrasi Nasional Usman Awang (AINUA) yang dianjurkan Yayasan Usman Awang dengan kerjasama Gabungan Pertubuhan Cina Malaysia (Huazong). Sasterawan Negara A. Samad Said merupakan penerima untuk tahun 2017. Maka falsafah kemanusiaan yang lebih luas ini, turut merupakan inti besar dalam rumus kesusasteraan pelancongan Usman Awang; ia adalah suara kebangsaan, malah sangat mendunia.

\section{Usman Awang sebagai tokoh sastera pelancongan kesusasteraan}

Dapatan kajian mengemukakan penyair Usman Awang sebagai tokoh sastera pelancongan Malaysia dengan mempertimbangkan latar kepengarangan dan latar kelahirannya di Kuala Sedili, Kota Tinggi, Johor. Walaupun tapak rumah kelahirannya sudah tiada, namun wajah Sedili yang diwakili Sungai Sedili, perkampungan nelayan, Sekolah Kebangsaan Sedili Besar, masih mengekori kenangan dan ketokohan Usman Awang. Begitu juga sempena namanya dibangunkan menerusi dua sekolah, iaitu Sekolah Kebangsaan Dato' Usman Awang, Kampung Kota Kechil, Kota Tinggi; dan Sekolah Menengah Kebangsaan Dato' Usman Awang (asalnya Sekolah Menengah Kebangsaan Taman Perling, Johor Bahru). Turut dinamakan "Jalan Dato Usman Awang", Tanjung Sedili yang merupakan jejak kesasteraan Usman Awang yang harus dipertahankan.

Sepertimana yang dilalui beberapa tokoh sasterawan dunia yang disebut awal antaranya Rudaki, Shakespeare dan Pasternak, pelbagai kegiatan dapat dirancang untuk membangunkan "Usman Awang" sebagai satu institusi kesusasteraan pelancongan Malaysia. Misalnya dapat dianjurkan pakej lawatan atau kembara sastera di sepanjang jejak kesasteraan Usman Awang seperti "Hari Mengenang Usman Awang" dengan pengisian mengenali karya Usman Awang yang dipamerkan di galeri atau muzium, bicara karya Usman Awang, penglibatan waris Usman Awang untuk menerangkan sejarah dan budaya setempat khasnya yang terkait dengan Usman Awang. Pihak kerajaan tempatan dengan kerjasama misalnya Yayasan Usman Awang dan Yayasan Warisan Johor sangat membantu dalam melanjutkan tradisi menghargai kepenyairan Usman Awang. Misalnya Yayasan Usman Awang secara giat pernah menjalankan acara di Sedili misalnya 
"Hening Puisi Seniman Paksi Rakyat" (Paksi) berlangsung dari 25-28 Julai 2015 di Jason Bay Resort, Tanjung Sedili, Kota Tinggi, Johor.

Jejak kesasteraan atas nama "Kembara Tulang-tulang Berserakan" juga dapat disediakan untuk melihat alir pemikiran Usman Awang dalam plot-geografi novelnya itu. Meneladani pengalaman "Rumah Pasternak" atau jejak kesasteraan Rudaki, kembara sastera ini juga dapat dilakukan secara maya atau atas talian. Prasarana yang cekap dan mesra pengguna harus dipastikan dapat dicapai dari mana-mana penjuru dunia. Pilihan bahasa juga harus dipertimbangkan. Capaian itu termasuk karya Usman Awang dalam genre puisi, cerpen, novel dan drama.

Selain daripada melanjutkan legasi kesusasteraan Usman Awang dalam bentuk lawatan ke "Sedili" dan menerusi jejak kesasteraannya, lensa rentas media dan alih wahana karya-karya penyair ini wajar digiatkan. Puisi-puisi yang dilagukan atau dipentaskan dalam bentuk drama muzikal perlu menjadi pengisian dan praktis dalam kalangan penggiat seni dan para pelajar yang mengikuti karya Usman Awang dalam silibus pendidikan. Begitu juga cerpen yang dihasilkannya boleh dipersembahkan melalui proses intertekstual transformasi ke dalam genre drama; atau novel tunggalnya, Tulang-tulang Berserakan yang dapat difilemkan. Sehingga kini karya Usman Awang yang pernah dialih wahana antaranya adalah puisi yang dilagukan seperti "Kekasih" (Ibrahim Bachik, Ahmad Ramli dan Kopratasa) dan "Tanahair" (iklan Hari Kemerdekaan 2013). Sementara beberapa puisinya seperti "Suara dari Pusara", "Mata Ayah", "Jebat Pahlawan Rakyat" dan "Surat dari Masyarakat Burung kepada Datuk Bandar", pernah melalui jalan intertekstual ke genre teater Dari Bintang ke Bintang (2015).

Meletakkan Sedili dalam peta pelancongan kesusasteraan negara, turut diharap dapat melonjakkan sumber pendapatan penduduk bukan hanya terkait dengan pendapatan sebagai nelayan (Zaimah, 2015). Keterkaitan dengan kegiatan pelancongan misalnya desa inap, pengangkutan (darat dan air), khidmat layanan mesra (hospitality) kulinari, dan kraf tangan. Namun bagi mencapai tingkat pendapatan yang lebih tinggi untuk kesejahteraan hidup, penglibatan pihak bertanggungjawab lain sangat diperlukan. Ia antara lain dapat dilakukan menerusi kegiatan pelancongan kesusasteraan khasnya menggunakan kerangka "jejak kesasteraan Usman Awang" bermula di Sedili.

\section{Kesimpulan}

Ternyata kehidupan yang bermanfaat itu adalah apabila terdapat kesalingan. Tulisan ini memperlihatkan kesalingan yang terbangun antara kesusasteraan dengan pelancongan. Kesalingan itu juga membentangkan sumbangan dan dukungan kesejahteraan warisan bangsa dalam kesusasteraan. Pada masa yang sama ia turut menumbuhkan peratus ekonomi yang membantu pendapatan negara. Kajian kesusasteraan pelancongan ini dilihat dari lensa antara disiplin yang antara lain turut menyorot proses alih wahana yang merupakan strategi atau kecekapan sastera.

Mengambil iktibar daripada sejarah panjang kesusasteraan dunia yang panjang termasuk Inggeris, Indonesia, Tajikistan, dan Turki, Malaysia menerusi ketokohan Usman Awang, turut diyakini mempunyai kelebihan yang tersendiri. Menggunakan beberapa kerangka kesusasteraan pelancongan dunia, kedudukan Usman Awang dan "Sedili" dapat memainkan peranan yang besar dalam wilayah pelancongan Malaysia dan antarabangsa. Idiosinkrasi Usman Awang sebagai penyair kemanusiaan, membawakan semangat mendunia. Cogan "kemanusiaan, keadilan dan perpaduan" dalam kebanyakan karya Usman Awang khasnya menerusi genre puisi, ternyata bersifat sejagat dapat diterima hampir semua pihak terutama dengan giatnya kerja penterjemahan 
puisi-puisinya ke pelbagai bahasa dunia. Dukungan yang aktif dari pelbagai pihak, kementerian, kerajaan tempatan, Yayasan Usman Awang, Yayasan Warisan Johor, persatuan penulis, penggiat seni, dan masyarakat setempat dengan pendekatan yang lebih tuntas dapat membangunkan Sedili sebagai tapak pelancongan kesusasteraan. Ia nantinya bukan sahaja menjadi satu bentuk pelancongan yang memberikan kesan lahiriah. Dampak yang lebih daripada itu melancong menerusi bahan kesusasteraan dapat membawakan kesan lebih dalam sebagai wahana bahasa nurani kemanusiaan.

\section{Penghargaan}

Terima kasih kepada GGP atas biayaan penyelidikan GGP-2020-022: Pembentukan Model Pelancongan Kesusasteraan di Malaysia. Terima kasih kepada Saudara Rozninah Abd. Azib atas kerjasama mengirim maklumat dan foto dari Kuala Sedili, Johor.

\section{Rujukan}

Akarcay, Pinar, \& Gokhan AK. (2017). A 'Language' of modern enchantments: The magic of literature in tourism. International Journal of Language Academy, 5/6, 12-25.

Anwar Ridhwan. (2015). Pemikiran Sasterawan Negara Usman Awang. Kuala Lumpur, Dewan Bahasa dan Pustaka.

Bidaki A.Z., \& Hosseini S.H. (2014). Literary tourism as a modern approach for development of tourism in Tajikistan. Journal of Tourism \& Hospitality, 3(120), 1-4.

Cevik, Samet. (2018). Interpretation of author-related literary tourism sites: Evidence from three sites in Turkey. Journal of Tourism Research, 20, 118-136.

Ferreira, A., Alén, E., Liberato, P., \& Liberato, D. (2020) Literary tourism: A cultural trip. In: Rocha, Á., Abreu, A., de Carvalho, J., Liberato, D., González, E., \& Liberato, P. (eds.). Advances in Tourism, Technology and Smart Systems. Smart Innovation, Systems and Technologies, 171. Springer, Singapore. https://doi.org/10.1007/978-981-15-20242_44

Firsova, Anastasia, \& Svetlana Myshlyavtseva. (2019). The literary heritage of Boris Pasternak as a resource for the Project Management in Tourism. Proceedings of the 4th International Conference on Innovations in Sports, Tourism and Instructional Science (ICISTIS 2019).

Ghetau, Leontina, \& Esanu, L. (2011). Literary Tourism as a Promoter of Cultural Heritage. 345353. Conference: Sustainable Development and Planning, Volume 150.

Haslina Usman. (2017). Anak Jiran Tionghua: 50 Sajak Perpaduan dan Keamanan. Kuala Lumpur, Yayasan Usman Awang.

Hoppen, A., Brown, L., \& Fyall, A. (2014). Literary tourism: Opportunities and challenges for the marketing and branding of destinations? Journal of Destination Marketing \& Management, 3(1), 37-47.

Jabil Mapjabil, Ratna Roshida Abd Razak Abd Razak, Mazdi Marzuki, \& Rosmiza Mohd Zainol. (2015). Pelancongan Islam: Suatu tinjauan konseptual dan relevannya di Malaysia, Geografia-Malaysian Journal of Society and Space, 11(1).

Karimi, S. (2019). Tolerance and pilgrimage: The experience of tolerance at Mevlana Jalal ad-Din Rumi mausoleum. Journal of Sociology of Social Institution, 5(12), 29-50. 
Kartal, Burak, Mustafa, Tepeci, \& Hakan, Atl1. (2015). Examining the religious tourism potential of Manisa, Turkey with a marketing perspective, Tourism Review, 70(3), 214-231.

Muhammad Haji Salleh. (2017). Seorang penyair, sebuah benua rusuh: Biografi Usman Awang. Kuala Lumpur, SIRD.

Nakamura, Kunio. (2015). Walking the Scenes of Hear the Wind Sing Exploring Murakami's World. $\quad$ ttps://medium.com/ignition-int/walking-the-scenes-of-hear-the-wind-singf2adc87cc6f8.

Nor Hashimah Jalaluddin. (2019). Produk media karya agung Malaysia. Jurnal Komunikasi. 35(3), 228-245.

Othman Puteh. (1999). Ini saya punya kerja. Kuala Lumpur, Utusan Publications.

Pejabat Kesihatan Daerah Kota Tinggi. (2021). KK Tanjung Sedili. https://www.pkdkt.com/index.php?option=com_content\&view=article\&id=62\&Itemid=6 1.

Preston, James. (1992). Spritual magnetism: An organizing principle for the study of pilgrimage. Dlm. Allan Morinis (ed.), Sacred journeys: The anthropology of pilgrimage, Westport, CT, Greenwood.

Rozninah Abd. Azib. (2021). Usman Awang. Temu bual, 4-7 Mac.

Swee Tin, Lim. (1999). Aspek-aspek kemasyarakatan dalam sajak-sajak Usman Awang tahun 1940-an dan 1950-an. Tesis Masters Sastera, Universiti Putra Malaysia.

Tudor, Gabriela-Cosmina. (2015). Film tourism - a successful journey for New Zealand: The way towards being the world's top film tourism destination. Cactus Tourism Journal, 12(2), 4553.

Usman Awang. (1982). Salam benua. Kuala Lumpur, Dewan Bahasa dan Pustaka.

Usman Awang. (1988). Gelombang. Kuala Lumpur, Dewan Bahasa dan Pustaka.

World Tourism Organization (WTO). (2014). Turkey and the WTO. http://dtxtq4w60xqpw.cloudfront.net/sites/all/files/pdf/infographic_2014_en.pdf

Yayasan Usman Awang. (2021). http://yayasanusmanawang.

Zaimah, R., Suhana Saad, Azima, A. M., Mohd Yusof Hussain, Mohd Samsudin, Mustaffa Omar, \& Ishak Yussof. (2015). Kesejahteraan subjektif: Kajian kes nelayan di Sedili, Kota Tinggi, Johor. Geografia-Malaysian Journal of Society and Space, 11(2), 87-94. 